University of Louisville

ThinkIR: The University of Louisville's Institutional Repository

Electronic Theses and Dissertations

1946

\title{
A survey of the Rhopalocera of Jefferson County, Kentucky.
}

Delbert Kenneth Weniger

University of Louisville

Follow this and additional works at: https://ir.library.louisville.edu/etd

Part of the Zoology Commons

\section{Recommended Citation}

Weniger, Delbert Kenneth, "A survey of the Rhopalocera of Jefferson County, Kentucky." (1946). Electronic Theses and Dissertations. Paper 2198.

https://doi.org/10.18297/etd/2198

This Master's Thesis is brought to you for free and open access by ThinkIR: The University of Louisville's Institutional Repository. It has been accepted for inclusion in Electronic Theses and Dissertations by an authorized administrator of ThinkIR: The University of Louisville's Institutional Repository. This title appears here courtesy of the author, who has retained all other copyrights. For more information, please contact thinkir@louisville.edu. 


\title{
UNIVERSITY OF IOUISVILIE
}

\section{A SURVEY OF THE RHOPAIOCERA OF JEFFERSON COUNTY: KENTUCKY}

\author{
A Disertation \\ submitted to the Faculty \\ Of the Graduate School of the University of Ioulsville \\ In Partial Fulfiliment of the \\ Requirements for the Degree \\ Of Magter of Arts \\ Department of Biology \\ By \\ Delbert Kenneth Weniger \\ Year \\ 1946
}


NAME OF STUDENT: Delbert Weniger TITIE OF THESIS: A Survey of the

$$
\frac{\text { Rhopalocera of Jefferson }}{\text { County, Kentucley }}
$$

APPROVED BY READING COMMITTEE COMPOSED OF THE FOLLOWING MEMBERS:

P. A. Davies

David A. Young, Jr.

William McCay

NAME OF DIRECTOR:

DATE: September 20, 1946 
CONTENTS

Introduction.................page I

General Llst for the county....... 8

Iffe zones, Iocal Regions of the county and Comparative Lists..... 95

Jefferson County Map............. 99

Bibllography................ 100 


\section{INTRODUCTION}

Extensive studies have been made of the distribution of butterfiles within the United states. These studies have been prompted both by the general interest in butterflies which arises from their beauty, and by the economic importance they attain in the larval stage. The results of such studies have been very good wherever they have been carried out with scientific standards and completeness.

The history of distribution studies of the butterflies has been marked by the continual narrowing of the territories considered in any preilminary study. At first it was attempted on the basis of a general observation of butterfly occurrences in the nation, to determine the ranges of the different species of butterflies. Inis could at best yield only approximations to the true ranges.

Soon 1t became the sty le to describe the range of a species in terms of states. The 
statement of the range thus consisted of a 11st of states where the species was found. Naturally this was a more satisfactory method and is still more or less followed. The morement continued, howerer, and it became obvious that there was need for yet more detalled studies of distribution. This called for a smaller unit of study - Since the previous units had been political dirisions of the country, It was natural to turn to the county for this new division. In practice it was found that the county was just about the right size for the purpose. Smaller areas, as $\$ 111$ be shown in this present study, have few distinctly different species of butterflies. of course there are different habitats within each county which are characterized by certain spec1es, but these do not have to do with the overall range since within its range any butterfly will be found in just such aiscontinuous areas presenting its habitat. 
The more recent work in this fleld, then, has been concerned with county surveys and reports of these surveys. These county reports, when presented and gathered, make possible the next step. This is the synthesis of a fair number of these reports from representative counties scattered over the state concerned into a list of the species of the state. It is evident that this method of establishing ranges of the butterflies is just the opposite of the older method and much more accurate in its result. some states have carried out these surveys until their butterfly population is definitely known and the exact part of the state over which a species flies is also known. Therefore any new extension of range can immediately be detected and any new arrival in the state followed.

A good example of a state worked out in this way is Kansas. Of one hundred and 
Iive counties in the state, over sixty have at least partly complete records of butterflies occuring in them. The time became ripe, therefore, for the synthesis of these records into a statewide list and a work has been published for that purpose. This paper Is by William D. Field (1938). Another state so worked out is Minnesota. Its lists are published in book form by Ralph W. Macy and Harold H. Shepard (1941). No similar work exists for Kentucky. The author intended to embark in some small way upon such a work for the state and investigated the posgibility of existing records. It soon was found that records of Kentucky butterflies were practically nonexistent or at least apparently so. As far as most collections are concerned, this state is practically a forgotten area. In fact, there was not discovered a single set of records for any part of the state. The state-wide l1st was, 
of course, ruled out for it can only be begun when there are at hand at least several county 11sts.

As the only possible contribution to the knowledge of Kentucky's butterflies at this time, the writer now presents a liat of the butterflies of Jefferson county, hoping that 1t w11l be the first of many more from other counties in the state.

Besides the simple listing of the species found, 1t has been decided to add a short description of each species and form. Th1s description is not necessarlly new in any way but is often in part based upon other descriptions in the literature. Nor is it complete, but designed to give some of the distinctive characters of the rarious butterflies that others may expect to find in Kentucky and thus possibly ald in their collecting. In the absence of studies of Itfe historles of the various butterflies in Kentucky it is assumed that our butterflies 
feed upon the same plants or closely related ones as they do in the rest of their range. Therefore these food plants, as recorded in the literature are given with the description of the butterfly as a further aid to Kentucky's collectors.

A list of the various names assigned to each butterfly during the period of 1ts study is given after its listing. The author has attempted to use, in this work, the most recently adopted classification and it may not correspond to the names by which some readers may have known the butterflies. To spare them confusion and much hard work these synonyms are 11sted. The writer follows the nomenclature and order of $\mathrm{K}$. W. Macy and H. H. Bhepard in the1r book, Butterfiles (1941) wh1ch conforms to that of J. MeDunnough's check Liat of the Lepldoptera of Canada and the United States (1938) in this paper.

A discussion of the life zones and faunal regions of Jefferson county is included 
at the end of this paper together with 11sts of species characteristic of these regions. The method of this study was continued observation of and collection of the butterflies of Jefferson county. An effort was made to visit and collect in as many of the county's different habitats as possible. Deep woods, bluegrass pastures, clover and alfalfa flelds, gardens, lawns and roadsides were collecting places. A large part of the collections were made near the eastern edge of the county where the writer lives, but several collecting trips were made to other parts of the county to make the list as inclusive as possible. The writer wishes to acknow ledge the kind help of Dr. William M. Clay of the University of Loulsville as director of this study. I also want to take this opportunity to thank Mr. Don. B. Stallings of Caldwell, Kansas for his suggestions and for identify ing a number of the more difficult species. 
GENERAL IIST

Family PAPILIONIDAE

The Swallowtalls

\section{Papil10 philenor Linneous}

Pipe-vine Srallowtall

Pap1lio philenor Linnaeus, Mantissa Plantarum, p. 535. 1771 .

-- Holland, Butterfly Book, p. 315.

p18. 2, 6, and 42, 1898.

---- Jordan in Seitz, Macrolepidop-

tera of the World, Vol. 5, p. 20, pl. 6a. 1907.

---- Macy and Shepard, Butterflies,

p. $42,1941$.

Laert1as philenor Seudder, Butterflies of the

Eastern United States and Canada, Vol. 2,

p. 1241, 1889.

--- comstock and comstock, How to

Know the Butterflies, p. 66, p1. 12, 1904 :

Pap1110 ph1lenor philenor clark, U.S. Nat1.

Mus. Bu11. No. 157, p. 174, p1. 30, 1932.

Descriptive notes. The wings of this species 
are dark above with metallic blue-green reflections, especially in the hind wings, and with a row of submarginal pale whitish spots. Underneath there is a row of seven large orange spots along the outer margin of the hind wing. The wing expanse is about four 1nches.

a. The spring form of this species called P. D. hirsuta Sk1nner, is smaller than the typlcal and has the body covered by long halrs. It was taken in Jefferson county on April 18, 1946. The day was partiy cloudy. The butterfly was feeding upon blooming spiraea.

b. The typical P. philenor Linn. was found flying over varled pasture plants on June 5, 1946. It mas seen occasionally up until the time of this writing which is August 21.

Food Plants. The main food plant of the specles Is Aristolochia, Dutchman's Pipe.

Distribution notes. The species occurs in 
southern New England, south through the southern states and west to California. In fact, It ranges over nearly the whole of the Eastern half of the United States and along the southern part to California. Eentucky 1s, therefore, well within 1te known territory.

\section{Pap1110 a jax Linnaeus}

The Black Swallowtall

Pap1110 a jax LInnaeus, Systema Naturae, 10th ed., p. 462, 1758 .

--- Macy and Shepard, Butterflies, p. 43, p1. 2, 1941.

Pap1110 polyxenes Scudder, Butterflies of the Eastern UnIted States and Canada, Vol. 2, p. 1353, 1889. -.-- comstock and comstock, How to Know the Butterflies, p. 62, pls. 4, 10, and 11, 1904.

Papilio asterlas Holland. Butterfly Book, p. 314, pls. 2, 6, and 40, 1898 . 
Papilio polyxenes asterias Jordan in Seitz, Macrolepidoptera of the World, Vol. 5. p. 23 , 1907 .

--- Holland, Butterfly Book,

$2 d \mathrm{Bd} .$, p. 314, 1931.

-.- Clark, U.S. Natl. Mus.

Bul1., No. 157, p. 191, pls. 40-44, 1932.

Descriptive notes. This butterfly is a

velvety black above with two rows of parallel

yellow spots on the outer half of both wings.

On the hind wings there are areas of blue

color between these spots which however are

not metallic as in the preceeding species,

but are made up of ordinary blue colored

ocales. On the underside the markings are

similar, but with a more orange color in the

spots. There is an orange spot with a black

center located near the anal angle of the

hind ring.

a. Typical P. a fax Linn. was netted in Jefferson county on March 30, 1946. It was fly ing about blooming Splraea. Other Individuals 
were seen commonly throughout the summer. Another was caught on May 6 and it was also typical P. afax. Mr. Don B. Stallings of Caldwell, Kansas kind ly checked the identification. At the time of this writing the specles was still commonly seen. Food Plants. Numerous plants of the Umbel11ferae or Parsley family are food for this species.

Distribution noteg. The butterfly is found throughout the Mississippi Valley and eastward.

It also ranges into the Southwest. Kentucky is close to the center of its territory.

3. Pap1110 glaucus Linnaeus

The Eastern Tiger Swallowtall

Pap1110 glaucus Linnaeus, Systema Naturae, 10th . p. $460,1758$. --. Jordan in Seltz, Macrolepidoptera

of the World, Vol. 5, p. 26, 1907. -.- Clark, U. S. NatI. Mus. Bull., No. 157, p. 179, pls. $33-40,1932$. 
---- Macy and Shepard, Butterflies,

p. $45,1941$.

Jasoniades glaucus Scudder, Butterflies of the Eastern United States and Canada, Vol. 2, p. 1289, 1889.

Papilio turnus Holland, Butterfly Book, p. 309, pls. 2, 6, and 43, 1898.

Descriptive notes. This is the swallowtall with a predominantly yellow color. The border of the wings is black containing a row of yellow spots. The hind wing is crossed in addition to this by one narrow black band running from the anterior margin posteriorally. The fore wing has four black bands running in the same direction, the inner most of which completely crosses the wings while each of the others is shorter than the one median to 1t. An orange and yellow spot occurs on the inner margin of the hind wing near the anal angle. The wing expanse is from three to five inches.

a. The typical P. glaucus Linn. was taken on March 29, 1946 in Jefferson county. It was 
feeding from the blossoms of Spiraea.

b. The form P. B. Glaucus Linn. of the dimorphic female of this species was captured on June 21, 1946. This is the dark form which 1s entirely black or dark brown above and below with only the yellow spots of the outer border present. The dark bands of the forewing of the male may usually be seen on the under side as bande which are slightly darker than the ground color. Both forms were st1ll on the wing at the close of this study. Food Plants. The larva will eat a great varlety of trees and shrubs, but seems to prefer Prunus, expectally w1ld Cherry. Dlstribution notes. The butterf ly occurs throughout North America from Newfound land to Alaska and south to the Gulf of Mexico.

\section{Pap1l10 tro1lus Iinnaeus}

Green-clouded Swallowtall

Pap1110 tro1 lus Linnaeus, Systema Naturae, 10th Ed., p. 459, 1758. 
-.. Holland, Butterfly Book, p. 315, pls. 2, 6, and 41, 1898. -.-- Comstock and comstock, How to Know the Butterflies, p. 59, p1. 9, 1904. ---- Jordan in Seitz, Macrolepidoptera of the World, Vol. 5, p. 27, pl. 8c, 1907. --- Macy and Shepard, Butterflies, p. 48, pl. 2, 1941.

guphoesdes trollus Scudder. Butterflies of the Eastern United States and Canada, Vol. 2, p. $1313,1889$.

Pap1l10 tro1lus tro1lus Clark, U.S. Natl. Mus. Bu11., No. 157, p. 189, p1s. 44-46, 1932 .

Descriptive notes. The upper surface of the wings are black with a row of marginal yellowish spots on the fore wing. The hind wing above has a bright orange spot near the middle of the costal margin and a marginal row of blue-green lunules. Inward from these lunules extends a cloud of blue-green color which, however, is not 1rridescent as in the case of Papilio 
philenor. It is distinguished from Papilio alax by the absence of the row of bright spots across the middle of the upper surface of the hind wing. The wing measurement is usually about four inches.

a. The typlcal P. trollus IInn. was netted in Jefferson county, Ky ., on May 5 , 1946. It was found in late afternoon on the bloom of Ribgrass, Plantigo lanceolata. It never became common during the summer but was occasionally seen and another specimen was captured on August 16. Food Plants. Sassafras and Benzoin or spicebush are the food plants. Distribution notes. From the M1s81ssipp1 Valley eastward to the coast. Kentucky is well in the range.

5. Pap1lio marcellus Cramer Zebra Swallowtall

Papilio marcellus Cramer. Papillons Exotiques, Vol. 2, p. 4, pl. 98, 1779. 
--- Jordan in Seitz, Macrolepidoptera of the Forld, Vol. 5, p. 39, pl. 14c, 1907. -.- Clark, U.S. Natl. Mus. Bull., No. 157, p. 197, pls. 48 and 49, 1932. - Macy and Shepard, Butterflies, p. 49,1941 .

Iphiclides afax Scudder, Butterflies of the Eastern United States and Canada, Vol. 2, p. 1264, 1889 . -n- Comstock and comstock, How to Know the Butterflies, p. 49, pl. 5, 1904. Pap1110 ajax Holland, Butterfly Book, p. 307 , p1s. 2, 6, and 44, 1898 .

Descriptive notes. The upper surface of the wings are a more or less clear white crossed by several black bands rather similar to those of Pap1110 glaucug but far more extensive. Near the anal angle of the hind wing is a bright red spot which is a good distingulshing characteristic. The tails are narrow and longer than those of any other swallowta1l. being often an inch or more in length. The 
wing spread is about three inches.

a. The second of the three seasonal

forms of tinis butterfly which occur, was found

in Jefferson county on May 16, 1946. It was

Ilying raplaly across a bluegrass pasture.

This form 1s called telamonides Felder and

Felder and is characterized by having two red

anal spots on the upper surface of the hind

wing instead of one.

b. The summer form, known as leconte1

Rothschild and Jordan, was taken later on

July 8. It has only the one red spot on the

hind wing and is larger than telamonides

with longer ta1ls. It was flying along the

edge of a thick woods at the time of capture.

Food Plants. The food plant is the parpaw,

Asimina triloba (Linn.).

Distribution notes. The species ranges from

Canada south to Florida and west nearly to the

Rocky Mounta1ns. 
Family PIERIDAE

The Wites. Yellows, and Orange-Tips

6. Anthocharis midea (Hubner)

Falcate Orange-Tip

Manciplum vorax midea Hubner, Sammlung

Exotischer Schmetterlinge, Vol. 1, pl. 142, 1809.

Euchloe midea Hubner, Verzelchniss bekannte

Schmetterlinge, p. 94, 1819.

Anthocharis genutia Scudder, Butterflies of the

Eastern United States and Canada, Vol. 2, p. 1147. 1889.

-- Clark, U.S. NatI. Mus. Bull.,

No. 157, p. 164, pl. 29, 1932.

Euchloe genutie Holland, Butterfly Book,

p. 284, p1s. 2, 5, and 32, 1898 .

Synchloe genutia comstock and comstock, How

to Know the Butterf 11es, p. 82, p1. 15, 1904.

Midea genut1a Rober in Seltz, Macrolepidoptera

of the World, Vol. 5, p. 96, pl. $28 \mathrm{~b}, 1910$.

Anthocharis midea Macy and Shepard, Butterflies,

p. 53. pI. 4, 1941. 
Descriptive notes. In this species the apex of the fore wing is hooked or falcate. The general color is white with a series of black marginal spots at the ends of the veins. In the male the hooked apex of the fore wing is colored a brilliant orange which the female lacks. The under side of the wings are white with part of the fore wings and all of the hind wings marbled with green and black in both sexes.

a. This species was captured in Jefferson county on April 20, 1946. At the time there were seen four of these butterflies which were all flying ceaselessiy about a blooming splraea bush but never alighting or feeding. 'curlously, all of these four were males with the orange coloring conspicuous. The specles was not seen again at any time during the rest of the season. Food Plants. The butterfly feeds upon different members of the mustard family or cruciferae. Distribution notes. The orange-tip is distributed over a broad belt extending from New 
Fngland westward and southward to Oh10, IIIInols and Texas (Macy and Shepard, 1941, p. 53). This finding of it in Kentucky is therefore important as widening this very restricted territory to include this state.

\section{Coliar philodice Godart} The Roadside Sulphur

colias philodice Godart, Encyclopedie

Methodique, Vol. 9, p. 100, 1819.

-.- Holland, Butterfly Book,

p. 291, pls. 1, 2, and 5, 1898.

--- Rober in Se1tz, Macrolepidoptera

of the World, Vol. 5, p. 91, pl. 27a, 1910.

-.-- Clark, U.S. Natl. Mus. Bull.,

No. 157, p. 158, pl. 27, 1932.

-.-- Macy and Shepard, Butterflies,

p. 56, p1. 3, 1941.

Eurymus philodice Scudder, Butterfiles of the Eastern United States and Canada, Vol. 2, p. 1111, 1889.

-.- copstock and comstock, How to

Know the Butterflies, p. 92, p1. 17, 1904. 
Descriptive notes. Although most authorities break this butterfly up into two specles, colias philodice Godart and colias eurytheme Bolsduval, calling the philodice the eastern species and ourytheme the western species, I cannot persuade myself that this is necessary or even warrented. I have collected the socalled eurytheme for years in Kansas and lately the so-called phllodice in Kentucky. I must acknowledge that I cannot see any difference between the two. In my search of the literature on the descriptions of the two species I found that comstock, although holding to the two species as distinct, states that except for the difference in ground color a description of philodice fits ourytheme as we 11 (comstock and comstock, 1904, p. 95). It being admitted that color is the only difference, it seems to me that there is little juatification for the division especially eince the various formo described cover well both colors. Fleld (1938, p. 180) has made the two 
species into one called philodice Godart. He then describes as eastern and western subspectè collas philodice philodice and Collas philodice eurt theme Boisduval. I cannot even see the justification for these subspec1ea, and in this paper regard the specimens caught in Kentucky as collas phllodice.

- The butterfly is of orange or yellow ground color. The wings are bordered on the upper side by wide black marginal bands. In the male these bands are solid while in the female they contain yellow patches on the upper wings. There 18 a black spot at the end of the cell in the fore wing and an orange or yellow one at the end of the cell in the hind wing. Underneath, the wings are a paler color thout the black borders and with the distal spots often a silvery color. a. On March 21, 1946 a butterfly answering to the description of the spring form, ariadne Edwards, was caught in Jefferson county. It was a male of a yellow ground color with the 
usual dark border and distal spots, the hind one of which was deep orange. In the center of the fore wing was a distinct orange flush of color. The wing spread was one and one quarter inches.

b. On the same day there was netted a form of this butterfly like the above in every respect but with no trace of orange elther in the fore wing or in the hind distal spot. The color was a lemon yellow. According to Field (1938, p. 180) there are two forms with this yellow color. Form eriphyle Edwards, 1s distinguished by an orange colored distal spot on the hind wing and is of the western subspecies eurytheme. The other is the typlcal collas philodice philodice which is the same but with the hind distal spot straw-colored Instead of orange and which occurs only in the east. Field also states that he has never found the latter in Kansas. I, however, have a specimen caught in cowly county, Kansas 
In the summer of 1944 wh1ch is without doubt collas philodice philodice having the lemon color with the straw-colored distal spot. It is entirely the same as this Kentucky specimen and constitutes in my opinion, a demonstration of the error of breaking the spectes up into subspecies.

c. The butterfly with its ground color of light orange throughout, which has been called variously a species, Colias eurytheme Bolsdural, or a subspecies, collas philodice eurytheme, was found in Jefferson county on April 2, 1946. I merely assign it the rank of a form and it is then, of course, designated as collas philodice form eurytheme Boisduval. d. On April 10, 1946 there was collected in this county a butterfly which was the form amphidusa Bolsduval. This has the ground color of a deep brilliant orange which is sometimes almost metallic in its reflections. Its wing expanse is larger being about one and one half inchea. 
e. The white form of the almorphic female was taken in Jefferson county on May 10, 1946. In this form the ground color is white more or less flecked with gray scales expecially on the hind wings. It is called alba Strecker.

f. On March 21, 1946 there was caught along with the specimen of ariadne, a specimen of this species which can only be described as an abberration of the form ariadne. It is the same size as the one caught at the same time and the ground color is ldentical, yellow with a cloud of orange at the center of the fore wing. The difference is in the black marginal border. On the upper side of the hind wing it is somewhat narrower than that of the typical ariadne.. It is not a solid band but is definitely broken up into rectangular patches by the yellow coloring which follows each vein all the way through to the margin. On the upper side of the fore wing the black marginal band is wholly wanting. 
The wing is thus solid yellow with the exception of the orange flush in the center and the black distal spot which is large and conspicuous. on the under side the wings are typical in every way •

This butterfly was found very commonly during the summer wherever dandelions, Taraxacum, or alfalfa bloomed. It was still on the wing at the end of the study. Food Plants. Members of the clover family, Irifolium.

Distribution notes. The butterfly, considering all the forms, ranges over nearly all of the Un1ted Stater and Canada.

\section{Phoebls sennae eubule (Innnaeus)}

$$
\text { cloudless sulphur }
$$

Pap1lio oubule Linnaeus, Systema Naturae, 12 th Ed., p. 764, 1768.

Calilaryas eubule scudder. Butterflies of the Eastern United States and Canada, Vol. 2, p. 1053, 1889. 
-.. Comstock and comstock, How to

Know the Butterflies, p. 88, pl. 16, 1904. -.- Holland, Butterfly Book, 2d Ed., p. 289, 1931.

Catopsilia oubule Holland, Butterfly Book, p. 286, pls. 2, 5, and 33, 1898. ---- Rober in Seitz, Macrolepidoptera

of the World, Vol. 5, p. 85, pla. 25a, 1910. Phoebls eubule eubule Clark, U.S. Natl. Mus. BuI1., No. 157, p. 163, p1. 21, 1932.

Phoeb1s sennae eubule Macy and Shepard, Butterflies, p. $59,1941$.

Descriptive notes. Th1s is the largest of the yellow butterflies common in this area. The male is completely of a bright canary yellow without any darker markings. The female is of the same color but with a discal brown spot and a row of small marginal brown spots on the fore wing. The wing expanse is about two and one half inches.

a. A solitary male of this species was seen flying rapidiy across the campus of the University of Louigville on July 23, 1946. 
The specles was not seen again.

Food Plants. Various species of Cassia a

leguminous plant.

Distribution notes. The species flies throughaut the southern part of the United States and most of New England. It is rare in the midwest.

9. Eurema 11sa (Boisduval and Leconte)

Iittie sulphur

Xanthidia 1isa Boisduval and Leconte,

Lepidopteres de l'Amerique Septentrionale, p. 53, p1. 19, 1833.

Eureme lisa Scudder, Butterflies of the Eastern United States and Canada, Vol. 2, p. 1087 , 1889.

-.-- Holland, Butterfly Book, 2d Ed., p. 302, 1931.

--- Macy and Shepard, Butterflies,

p. 61, 1941.

Terlas lisa Holland. Butterfly Book, p. 297, pla. 2, 5, and 37, 1898. --- Rober in Seltz, Macrolepldoptera of the World, Vol. 5, p. 83, pl. 24d, 1910. 
Eurema euterpe Comstock and comstock, How

to Know the Butterflies, p. 98, pl. 15, 1904. Terias euterpe d'Almelda, Memorias do

Instituto Oswaldo Cruz, No. 31, p. 251, 1936. Descriptive notes. This is a small butterfly which 1s of yellow color with dark borders on the wings, broad at the apex of the fore wing and becoming narrower as they proceed back, finally running out before reaching the anal angle of the hind wing.

a. A single specimen of this butterfly was netted in Jefferson county on June 28 . 1946. It was on the wing at the time. Food Plants. Cassia and clover, Trifolium, are both food plants.

Distribution notes. This species ranges north from Central America north to New Ingland and west to the Rocky Mountains. It is not common this far north.

10. Eurema nicippe (cramer)

$$
\text { Sleepy Yellow }
$$


Papilio nicippe Cramer, Papillons Exotiques, vol. 3, p. 31, p1. 210, 1782 .

Xanthidia nicippe Scudder, Butterflies of the Eastern United Stater and Canada, Vol. 2, p. $1066,1889$.

Terlas nicippe Holland, Butterfly Book, p. 296, pls. 2, 5, and 37, 1898. -..- Rober in Seitz, Macrolepidoptera

of the Wor $1 d$, Vo1. 5, p. 81, pl. 24a, 1910. Eureme nicippe comstock and comstock, How to

Know the Butterflies, p. 97, p1. 15, 1904. -.-- Holland, Butterf'ly Book, 2d

Ed., p. 301, pla. 2, 5, and 37, 1931. --- Clark, U. S. Natl. Mus. Bull., No. 157, p. $149, \mathrm{pl} .28,1932$. -.-- Macy and Shepard, Butterflies,

p. $62,1941$.

Descriptive notes. The butterfiy is bright orange with broad black borders. These borders are wider on the lower wings than on the fore wings. There is a black discal spot on the fore wing. a. A single individuel of this species 
was found on the wing in Jefferson county on July 6, 1946. Th1s was the only appearance of the butterfly during the season. Food Plants. This species also feeds upon Cassia and other leguminous plants. Distribution notes. The butterfly is common in the south and occurs into New England. In th1s part of the country it has been reported only as far as Southern Indiana and Illinois. Th1s Kentucky area is near its northern Iimit. Its measurement is up to two and one half Inches.

11. Pleris protodice Boisduval and Leconte Checkered White

Pieris protodice Boliduval and Leconte, Iepidopteres de I'Amerique septentrionale, p. 45, pl. 17, 1833. -.- Holland, Butterfly Book, p. 278, pla. 2, 5, and 34, 1898 . Rober in Seitz, Macrolepidoptera of the world, Vol. 5, p. 59, pl. 19c, 
1909.

-.-- Clark, U, S. Nat1. Mus. Bull.,

No. 157, p. 166, pl. 29, 1932.

--- Macy and Shepard, Butterflies,

p. 65, p1. 4, 1941.

Pontla protodice Scudder. Butterflies of the

Eastern United States and Canada, Vol. 2,

P. $1163,1889$.

-.-- Comstock and comstock, How to

Know the Butterflies, p. 73, pl. 13, 1904.

Descriptive notes. This butterfly is white with a black bar at the end of the cell in the fore wing and other black markings more or less scattered over the wings. Many of these dark marks and lines follow the veins. The under side is similar ly marked, but with the dark area not as heavy. The wing spread is up to two inches.

a. The spring form, characterized by a smaller size and reduced markings and with an overall yellowish brown color on the under slde of the hind wings, was caught in Jefferson 
county on Apri1 1, 1946. It is called P. vernalig Edwards.

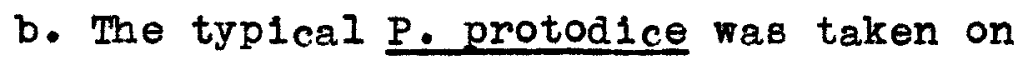
May 11, 1946. It was still occasionally found at the end of the period covered by this study. Food Plants. Numerous cruciferae.

Distribution notes. It is found all over the United states and Canada and south into central America.

\section{Pleris rapae (Iinnaeus) . Cabbage Butterfly}

Pap1110 rapae Innaeus, Systema Naturae, 10th Ed., p. 468, 1758.

Pleris rapae Scudder, Butterflies of the Eastern United States and Canada, Vol. 2, p. 1205, 1889. -.- Holland, Butterfly Book, p. 280 , pls. 2, 5, and 35, 1898. -..- comstock and comstock, How to Know the Butterflies, p. 78, p 1s. 3 and 14 , 1904.

--- Rober in Seltz, Macrolepidoptera of the World, Vol. 5, p. 58, pl. 19b, 1909. 
--- Clark, U. S. Natl. Mus. Bull.,

No. 157, P. 170, pls. 28 and 29, 1932.

--- Macy and Shepard, Butterfliea,

p. 67, 1941.

Descriptive notes. The wings are white with the apex of the fore wing black. There is a black dot just below the end of the cell in the fore wing and another on the costal margin of the hind wing. The female has an extra black dot just below the first one on the fore wing. The under side of the hind wing is gray in typlcal rapae. The wings expand about two inches.

a. Typical rapae was observed in Jefferson county on March 20, 1946. It was not assoclated with any flower or plant but was flying.

b. The common summer form yreka Reakirt was caught in th1s county on May 23, 1946. It differs from the above form in that the underside of the wings are without any sign of dark color but instead are white, often shaded with pale yellow. The butterfly was seen throughout the rest of the period of 
study .

Food Plants. The food plant is cruciferae, especially cabbage.

Distribution notes. This species was introduced Into North America about 1860. It rapidiy spread over most of the continent.

\author{
Family DANAIDAE
}

The Royal Butterflies

13. Danaus plextppus (IInnaeus)

The Monarch

Papilio plexippus Linnaeus, Systema Naturae, 10th Fd., p. 471, 1758.

Danais archippus Fabricius, Entomologia

Sy stemat1ca, Vol. 3, p. 49, 1793.

-..- Haensch in Se1tz, Macrolepidop-

tera of the World, Vol. 5, p. 113, 1909. Anosia plexippug Scudder, Butterflies of the

Eastern United States and Cansda, Vol. I, p. $720,1889$.

--- Holland, Butterfly Book, p. 82,

p1. 7, 1898.

-.. Comstock and comstock, How to

Know the Butterflles, p. 204, pls. 1, 28 and 
32, 1904.

Dana1s plexippus Holland, Butterfly Book, $2 d$ Id., p. 68, 1931. -.- Clark, U.S. Natl. Mus. Bull.,

No. 157, p. 115, pls. 6 and 58, 1932. -..- Macy and Shepard, Butterflles, p. 77, pl. 4, 1941. Descriptive notes. The butterfly is orangebrown with the velns black, and with a black border which encloses two rows of white spots. The male has a prominent black enlargement along the third vein from the inner margin of the hind wing. The wing expanse is about four inches.

a. This butterfly was taken on April 20, 1946 in Jefferson county. It was never very common, but was occasionally seen throughout the rest of the study. It was usually found in flight.

Food Plants. It feeds upon milkweed (Ascleplas) . Distribution notes. All of North America and into central America is this species range. 
Family SATYRIDAE

The Forest Nymphs

14. Megisto eurytua (Fabricius)

Iittle Wood Satyr

Pap1110 eurytus Fabricius, Entomologia Systematica, p. 487, 1775.

Clssia eurytus Scudder, Butterfiles of the Eastern United States and Canada, Vol. 1, p. $214,1889$.

-.-- Comstock and comstock, How to

Know the Butterflies, p. 197, p1. 30, 1904. Neonymphs eurytus Holland, Butterfly Book, p. 203, pls. 3,4, and 25, 1898 . -.- clark, U.S. Natl. Mus. Bull., No.

157, p. 63, pls, 1 and $2,1932$.

Euptychia eurytus Weymer in Seitz, Macrolepidoptera of the Forld, Vol. 5, p. 202, pl. 47c, 1911. ---- Holland, Butterfly Book, 2d Bd. , p. 180, 1931.

Meg1sto eurytus Macy and Shepard, Butterflies, p. 81, p1. 2, 1941.

Descriptive notes. The upper side of the wings 
1s a dark brown with two yellow-ringed black spots near the outer margin of the fore wings. There are from one to several of these spots along the marging of the hind wings. The under side 18 similar th the larger spots showing double silver dots in them.

a. This butterfly was first encountered in Jefferson county on May 23, 1946. From that day on 1t was fairly common in the woods where it flew through and among the wood plants in its queer halting manner. It was last seen on August 9.

Food Plants. The larvae feed upon various grasser (Poaceae).

Distribution notes. The butterfly occurs over most of the United States and Canada east of the Rocky Mountains.

\section{Fam1 ly NYMPHALIDAE}

The Brugh-Footed Butterflies

15. Dione van1llae (IInnaeus) 
Pap1l10 Vanillae Linnaeus, Systema Naturae, 10th Ed., p. 482, 1758.

Agraulis vaniliae Scudder, Butterfiles of the Eastern United States and Canada, Vol. 3, p. 1814, 1889. -.- Comstock and comstock, How to Know the Butterflies, pp. 107-8, p1. 18, 1904. Dione vanillae Holland, Butterfly Book, p. 97 , p1. 8, 1898.

---- Seltz, Macrolepldoptera of the World, Vol. 5, p. 40I, pl. 84f, 1913. -.-- comstock, Butterflles of california, p. 76, 1927. -..- Macy and Shepard, Butterflies, p. $92,1941$.

Descriptive notes. The upper side of the wings 1s a reddish brown. The reins are dark in the upper wings with the dark color expanding into large spots near the margin. There are several other dark spots on the fore wings, those nearer the costal margin with white centers. The hind wings above have three dark spots in 
the center and a marginal black band which contains a row of brownish spots. Underneath, the fore wing is brown in the center of th several silver centered black spots and with several large silver spots at the apex. The hind wing is dark brown underneath with a large number of sliver spota. The largeat one is almost divided by a large cleft. a. Th1s species was taken in Jefferson county on June 18, 1946. It was the only observed appearance of it during the season. Food Plants. Passiflora (Passion flower). Digtribution notes. The butterfly ranges through the southern half of the United States. In Kentucky it is probably only a straggler.

16. Argynnis aphrodite (Fabricius) Aphrodite Fritillary

Pap1110 aphrodite Fabricius, Mantissa Insectorum, Vol. 2, p. 62, 1787 . Arginnis aphrodite Scudder, Butterflies of the Eastern United States and Canada, V01. 1, 
p. 563, 1889 .

-.. Holland, Butterfly Book, p. 107, pls. 5 and 14, 1898.

-w- Comstock and comstock, How to Know

the Butterflies, p. 117, p1. 21, 1904.

--- Iehmann in Seltz, Macrolepidoptera

of the World, Vol. 5, p. 409, p1. 85d, 1913.

-m Clark, U. S. Nat1. Mus. Bull.,

No. 157, p. 112, pls. 16-20, 1932.

-.- Macy and Shepard, Butterflies,

p. 97, 1941.

Descriptive notes. This Fritillary has the typlcal complex pattern of dark spots upon a brown ground color on the upper wing. This color 18, however, darker than that of most other related species. On the under side of the wings there are the usual wide-spread s1lver spota of the fritillaries. It may be distinguished from other related species by the absence of the yellow submarginal band between the two outer rows of silver spots. The wing spread is two and a half inches. 
a. This species was taken on June 20, 1946 and seen rather commonly from that time unt1l about July 30, when it was last seen. Food Plants. Violets (V10la) are the food plants. Distribution notes. The butterfly occurs in Canada and over the northern half of: the eastern part of the United States. Kentucky is at the southern edge of its range.

\section{Phyclodes gorgone (Hubner) Gorgone crescent-Spot}

Dryas reticulate gorgone Hubner, Sammlung Exotische Schmetterlinge, Vol. 1, pl. 4l, 1810.

Melitaes 1smeria Bo1sduval and Leconte, Iepldopteres de I'Amerique Septemtrionale, p. 168, 1833.

Charidryas ismerla Scudder, Butterflies of the Eastern Unlted States and Canada, Vol. 3. p. $1810,1889$.

Phyclodes 1amerla Holland, Butterfly Book, p. 152, p1. 17, 1898. --- Rober in Se1tz, Macrolepldoptera 
of the World, Vol. 5, p. 436, pl. 89c, 1913. Phyclodes gorgone Holland, Butterfly Book,

2d Ed.. p. 139, pl. 17, 1931. --- Macy and Shepard, Butterflies,

p. 108, 1941.

Phyclodes carlota Clark, V.'S. Natl. Mus. Bull., No. 157, p. 247, pl. 18, 1932.

Descriptive notes. The upper side of the wings is fulvous, w1th heavy black borders which in this species enclose a marginal row of white spots. There is black contalning fulvous spote on the inner parta of the wings. The under side of the wings is chocolate brown with the basal part of the hind wings containing a silver bar and numerous silver spots and 11nes. The outer part contains five small black spots some of which enclose white areas. Near the margin is a row of sllver crescents which are thin and greatly bent. The wings measure about one and a quarter inches. a. This butterfly was taken in Jefferson 
county on June 29, 1946. It was not seen again Food Plants. The members of the family Aster are the food plants.

Distribution notes. The butterfly is a Midwestern species. It is only occasionally reported east of Kansas. However there seem to be stragslers farther east at times. It has been reported from different parts of the East such as Minnesota, Michigan, etc. Evidently this was another such straggler.

\section{Phyciodes nycteis (Westwood)}

Silver crescent

Melitaea nycte1s Doubleday, Westrood and Hewitson, Genera of Diurnal Lepidoptera, Vol. I. p. 181, pl. 23, 1847 .

Charidryas nycteis Scudder, Butterfiles of the Eastern United States and Canada, Vol. I, p. 658, 1889.

--- Comstock and comstock, How to Know the Butterflles, p. 127, pl. 22, 1904. Phyclodes nyctels Holland, Butterfly Book, 
p. 151, p1s. 5 and 17, 1898.

--- Rober in Seitz, Macrolepidoptera

of the World, Vol. 5, p. 435, pl. 89c, 1913.

-.-- Macy and Shepard, Butterflies,

p. 109, 1941.

Descriptive notes. This species is similar to gorgone on the upper side of 1ts wings but it lacks the marginal row of white pots. On the under side the wings are much more pale in color with the marginal lunules wider and less bent. The expanse of the wings is one and three-quarter inches.

a. This butterfly was captured on May 24, 1946 in Jefferson county. From that time on it became very common and was to be seen at almost any time about the moist edges of pools of water during the whole study. Food Plants. Various compositae such as sunflowers and asters.are the food plants. Distribution notes. Reported to be from Maine to North Carolina and west to the Rockies. 
Kentucky is thus well within the range.

\section{Phyclodes tharos (Drury)}

The Pearl crescent

Danaus tharos Drury, Illustrations of Natural

History, Vol. 1, pp. 43-44, pI. 21, 1770.

Phyclodes tharos scudder, Butterflies of the

Eastern Unlted States and Canada, Vol. 1 ,

p. 629,1889 .

-.- Holland, Butterfly Book, p. 153,

pls. 5 and 18, 1898.

-.-- comstock and comstock, How to

Know the Butterflies, p. 129, p1. 22, 1904.

--- Rober in Seitz, Macrolepldoptera

of the World, Vol. 5, p. 436, pl. $89 d, 1913$.

-.. Clark, U.S. NatI. Mus. Bull.,

No. 157, p. 97, pls. 7, 13, and 19, 1932.

-..- Macy and Shepard, Butterflies,

p. 110, 1941.

Descriptive notes. The upper surface of the wings is orange-brown with black borders and black basal portion. The hind wing has a row of small black spots running along the border. 
On the underside there is a faint network of Ines of different shades of brown. The rows of lunules on the hind wings of the two previous species are absent or replaced by black. The wing measurement 1s. rarely over one and a half inches.

a. The sprine form marcia Edwards, which has the underside very IIghtly Iined was netted in Jefferson county on April 20, 1946.

b. The typical tharog was taken here on June 14, 1946. It has the markings of the underside darker. It was very common from that date on to the end of the observations. rood Plants. This species also feeds upon the aster. Distribution noteg. The species ranges over all of the United States and Southern canada except the Pacific coast.

\section{Polygonia interrogation1s (Fabriclus)} Question Mark

Papilio 1nterrogationis Fabriclus, Supplementum 
Entomologlae Systemat1cae, p. 424, 1798.

Polygonia interrogationia Scudder, Butterflies of the Eastern United States and Canada, Vol. 1, p. 319, 1889.

-.-- Comstock and comstock, How to know the Butterflles, p. 134, pl. 23, 1904. -n- Seltz, Macrolep1doptera of the World, Vol. 5, p. 455, pl. 93a, 1914. --- Holland, Butter $1 \mathrm{y}$ Book, 2d Ed., p. 149, 1931. --- Clark, U.S. NatI. Mus. Bull., No. 157, p. 94, p1. 10, 1932. ---- Macy and Shepard, Butterflies, p. 112, 1941 .

Grapta interrogationis Holland, Butterf ly Book, p. 164, p1s. 1, 3, 4, and 19, 1898. Descriptive notes. The upper side of the wings of this butterfly is orange but with the outer half clouded with a dark brown and the rest spotted with black. The under side is wood colored with light and dark brown and with a 
ollver mark in the center of each hind wing. This mark gives the species its name, but it is really shaped more like a semicolon.

a. Form P. 1. fabricil Edwards was captured on May 18, 1946, in Jefferson county It is characterized by having the wings more angular and the tails slightly longer. The outer portion of the hind wing is also lighter in color and contains a submarginal row of orange spots. The individual was found stting on the ground sunning 1tself.

b. The typical 1nterrogationis described above was taken in this county on June 2, 1946. It was found sunning itself on the leaves of an elm tree (Ulmus). The species was seen regularly throughout the study. It was especially to be found in an orchard where a dozen or more could be soen at almost anytime feeding upon some rotting peaches. Food Plants. The food plants seem to be varied, incluaing Urtica or nettles, Humulus or hops, 
Tilia or basswood and UImus or the elms. Distribution notes. Occuring all over Canada and the United States with the exception of the Pacific coast.

\section{Nymphalis antiopa (Iinnaeus) Mourning Cloak}

Papilio antiopa Linnaeus, Systema Naturae, 10th Ed., p. 476, 1758.

Euvanessa antiopa Scudder, Butterflies of the Eastern United States and Canada, Vol. 1 , p. 397,1889 . -.-- Comstock and comstock, How to Know the Butterflies, pp. 148-51, pls. 2, and $25,1904$.

Vanessa antiopa Holland, Butterfly Book, p. 169, pls. 1, 3, and 4, 1898. --- Seltz, Macrolepidoptera of the World, Vol. 5, p. 457, pl. 93f, 1914. Aglais antiopa Holland, Butterfly Book, 2d Ed., p. 153. 1931.

Vanessa antlopa creta clark, U.S. Natl. Mus. 
Bu11., No. 157, p. 91, pl. 9, 1932.

Nymphalis antiopa Macy and shepard, Butterflies, p. 121, 1941.

Descriptive notes. The upper surface of the wings are a very dork maroon. There is a rather broad marginal band of yellow around both wings and two yellow bars along the costal edge of the fore wings. Just inside the yellow band is a band of black enclosing a row of bluish spots. On the under side the bands around the margin are white with black flecks. The rest of the wings underneath are blueblack in color with many fine lines. The wings may measure from two and a half to three inches.

a. This butterfly was found flying along the edge of a woods in Jefferson county on March 20, 1946. It was apparently one of the generation which had hibernated during the winter, since it is stated that the first new adulta emerge in late June and early July (Macy and Shepard, 1941, p. 122). The species 
was not seen again.

Food Plants. Populus (Poplar), Ulmus (Elm), and Salix (willow).

Distribution notes. This species is found all over the Northern Hemisphere.

\section{Vanessa atalanta (Linnaeus) \\ Red Admiral}

Pap1lio atalanta Linnaeus, Systema Naturae, loth Ed., p. 478, 1758.

Vanessa atalanta Scudder, Butterflies of

the Eastern United States and Canada, Vol. 1,

p. 441, 1889.

-.-- Comstock and comstock, How to

Know the Butterflies, p. 154, p1. 26, 1904. -..- Holland, Butterfly Book, 2d Ed., p. 153, 1931 .

--.- Macy and Shepard, Butterflies,

p. 122, pl. 1, 1941.

Pyrameis atalanta Holland, Butterf ly Book, p. 170, pls. 3, 4, and 43, 1898. -.-- Seltz Macrolepidoptera of the 
Wor Id, Vol. 5, p. 458, pl. 94a, 1914. --- clark, U.S. Natl. Mus. Bull,, No. 157, p. 84, pl. $7,1932$.

Descriptive notes. The wings are black above with a bright red band runing across the fore wing and with several white spots near the apex of the fore wing. The hind wing is bordered by a red band containing several black dots. The lower surface of the fore wing is practically as the above surface, but the lower surface of the hind wing is of mottled black and gray. The expanse is two 1nches.

a. Th1s well-known species was first found in Jefferson county this season on May 6. It was observed in a dense grove of Red Cedar (Juniperus virginiana) where it was flying about and alighting upon the trunks of the trees. The species was seen fairly common until August 10 when it was last seen. Food Plants. Humulus (hops) and Urtica (nettles). 
Distribution notes. The species is almost cosmopolitan, occuring all over North America, Europe, and over most of Asia and Africa.

23. Vanessa virginiensis (Drury)

Painted Beauty

Papilio cardue Virginiensis Drury, Illustrations of Natural History, Vol. 1, pp. 10-11, p1. 5, 1770 .

Vanessa huntera Geyer in Hubner, Sammlung Exotiache Schmetterlinge, Vol. 3, pl. 7, 1828.

--- Scudder, Butterflies of the Eactern United States and Canada, Vol. 1, p. $457,1889$.

-.-- comstock and comstock, How to

Know the Butterflies, p. 156, p1. 26, 1904.

Pyramels huntera Holland, Butterf ly Book, p. 170 , pls. 1, 3, 4, and 33, 1898.

Pyrameis huntera form virginiensis seltz, Macrolepldoptera of the Forld, Vol. 5, p. 459, pl. 94b, 1914 . 
Vanessa Virginiensis Holland, Butterfly Book, 2d Ed., p. 154, 1931. -..- Macy and Shepard Butterflies,

p. 123, 1941.

Pyramels V1rginiengis Clark, U.S. Natl. Mus. Bul1., No. 157, p. 86, p1. 27, 1932. Descriptive notes. The wings above are light brown in the centers. There is much black coloration along the margins of the fore wing and the apex is black containing several white spots. The hind wings are bordered by two narrow black bands separated by a row of light brown lunules. Farther on there is a row of rather indistinct black spots pupilied with blue. Underneath the fore wing is duplicated with all of the colors much lighter and the ground color sometimes a decided pink. The hind wing is gray and brown with the center crossed by several distinct branching Iines of white. There are two large submarginal eye spots on this wing. The wing spread is two inches. 
a. On May 5, 1946 several specimens of this specles were found in Jefferson county feeding upon blooms of the blackberry or Rubus. The butterfly was observed occasionally until the project was ended on August 21. Food Plants. The larvae feed upon Artemisia (mormwood or sagebrush), Arctium (burdock), Gnaphalium (cudweed), and Antennaria (everlasting).

Distribution notes. All of North America is included in this butterfly's territory.

24. Vanessa cardu1 (Iinnaeus) Painted Lady

Pap1lio cardu1 Linnaeus, Systema Naturae, 10th Ed., p. 475, 1758. Vanessa cardul Scudder, Butterfiles of the Eastern Un1ted States and Canada, Vol. 1, p. $469,1889$. -n- comstock and comstock, How to Know the Butterflies, p. 158, p1. 26, 1904. 
--- Holland, Butterlly Book, 2d Ed.,

p. 154, 1931.

-.-- Macy and Shepard, Butterflies,

p. 125, p1. 4, 1941.

Pyramels cardui Holland, Butterfly Book, p. 170, pls. 1, 3, and 4, 1898 .

---- Seltz, Macrolepddoptera of the

world, Vol. 5, p. 458, 1914.

--m Clark, U.S. Natl. Mus. Bull.,

No. 157, p. 88, p1. 8, 1932.

Descriptive notes. The description of

V. Virginiensis fits cardui equally except for the facts that the submarginal row of spots

on the upper side of the hind wing is made

up of more distinct spots which lack blue

pup1ls and that there are more than two large

eye spots on the under side of each hind wing.

The wings expand to two inches.

a. V. cardui was taken in Jefferson county

on June 3, 1946, from which time it was

occasionally seen until the end of the

observations. 
58.

Food Plants. Included in the usual preference are nettle (Urtica), hollyhocks (Althaea), burdock (Arctium) and thistle (oirsium). Distribition notes. This is the most widely distributed of all known butterflies since it is found in almost all temperate regions and in many tropic regions of the earth (Holland, 1903, p. 170).

25. Junonia coenla Hubner

The Buckeye

Junonia coenla Hubner,. Sammlung Exotische

Schmetterlinge, Vol. 2, pl. 32, 1822.

---- Scudder, Butterflies of the

Eastern United States and Canada, Vol. 1 , p. 494, 1889 .

-.- Holland, Butterfly Book, p. 173,

pls. 3, 4, and 20, 1898.

--- Comstock and comstock, How to

Know the Butterflies, pp. 160-62, pl. 24, 1904 . 
--- Macy and Shepard, Butterflies, p. 126, pl. 1, 1941.

Precis lavinia form coenia seitz, Macrolepidoptera of the Forld, Vol. 5, p. 461, p1. $94 e, 1914$. Junonia lavinia coenia Clark, U.S. Natl. Mus. Bull., NO. 157, p. 79, pl. 7, 1932. Descriptive notes. The wings above are a dark brown. The fore wing has two eye spots, the aplcal one very small and the other very large. crossing this wing and partly enclosing the large eye spot is a white band. Basal to it are two short orange-red bands. The hind wing has two large eye spots. The wing expanse is very variable (Field, 1938, p. 89) but the average is about two inches.

a. A single specimen of this butterfly was caught in Jefferson county on July 8, 1946. It was feeding on clover (Trifolium) blooms. Food Plants. The caterpillar feeds upon plantain (Plantago) and snapdragon (Artirrhinum). Distribution notes. This is a southern species 
60.

ranging from South America as far north as northern California, Iowa and Illinois. Kentucky is therefore near the northern Iimit of 1ts territory.

26. Basilarchia astyanax (Fabricius)

Red Spotted Purple

Papil10 astyanax Fabricius, Entomologia Sy s temat1ca, p. 447,1775 .

Bas larchia astyanax Scudder, Butterflies of the Eastern United States and Canada, Vol. 1, p. 280, 1889. --- Holland, Butterfly Book, p. 183 , pls. 3, 4, and 22, 1898. comstock and comstock, How to Know the Butterfl1es, pp. 166-67, pl. 27 , 1904.

--- Macy and Shepard. Butterflies, p. 130,1941 .

Imenit1s astyanax Seitz, Macrolepidoptera of the World, Vol. 5, p. 534, pl. 109e, 1915.

Bas1larchia arthemis astyanax Clark, U.S. Natl. 
Mus. Bu11., No. 157, p. 76, p1. 5, 1932. Descriptive notes. The wings are black, with an elusive blue-green luster. The only markings above are three rows of blue spots on the outer third of the wings. Underneath there are several conspicious red spots. The expanse is at least three inches. a. Mis beautiful species was taken in Jefferson county on the campus of the Univergity of Louisville, June 14, 1946 and was seen occasionaliy after that time. It is an unusual butterfly in regard to habits. It was not seen feeding on any flowers but was often flying or sunning 1tself. It was often seen in town, but rarely in the country. Food Plants. The larva feeds upon a variety of plants, among them Salix (willow), Quercus (oak), cydonia (quince), Malus (apple), crataegus (hawthorn), and Prunue (cherry). D1stribution notes. It occurs throughout the United states east of the Rocky Mountains. 
27. Bas1larchia archippus (Cramer)

The Viceroy

Papilio archippus Cramer, Papillons Exotiques, VOI. 1, p. 24, pl. 16, 1779.

Basilarchia archippus Scudder, Butterfiles of the Eastern United States and Canada, Vol. 1 , p. 267, 1889.

-n- Comstock and comstock, How to Know the Butterflies, pp. 170-73, p1. 28, 1904.

---- Holland, Butterfiy Book, $2 d$

Ed., p. 165, 1931. --- Clark, U.S. Natl. Mus. Bull.,

No. 157, p. 78, pl. 6, 1932.

-n- Macy and Shepard, Butterflies,

p. 130, p1. 4, 1941.

Basilarchia dislppus Holland, Butterfly Book, p. 185, pls. 3, 4, and 7, 1898.

Imenitis archippus Seltz, Macrolep1doptera of the World, Vol. 5, p. 534, pl. 109f, 1915. Descriptive notes. This specles is very unlike the other members of the genus. The ground color is brownish red with black borders 
containing white spots. The velns are outined in black and there is a narrow black line across the hind wing from the costal margin to the anal angle. It is famous for its mimicracy of the Monarch, Danaus plexippus (IInnaeus). The description of the Monarch fits it well with the following exceptions. There is only one row of white spots in the black border and the narrow band of black across the hind wing which is never present in the Monarch. These two characters serve to distinguish it from that species. The wing spreadisfrom two and a half to three inches.

a. This butterfly was netted on May 6 , 1946 in Jefferson county. It was in a marshy part of a blue gross pasture, sunning itself upon a rock. It was not common here, being seen only at widely separated intervals and last on August 9. Food Plants. Salix, Populus, Quercus and Prunus. Distribution notes. It occurs over the United States and southern Canada east of the Rocky Mountains. 
28. Asterocampa celtis (Boisduval and Leconte) Hackberry Butterfly

Apatura celtis Boisduval and Ieconte,

Lepidopteres de l'Amerique septintrionale, p. 210, p1. $57,1833$.

Chlorippe celtis Scudder, Butterflies of the Eastern United States and Canada, Vol. 3. p. $1788,1889$.

-- Holland, Butterfly Book, p. 189,

p1. 23, 1898.

-n- Comstock and comstock, How to

Know the Butterflies, p. 174, pl. 29, 1904. --- Clark, U.S. Nat1. Mus. Bull.,

No. 157, pp. 74-75, pl. 4, 1932 .

Asterocampa celtio Rober in Seitz, Macrolep1doptera of the forld, Vol. 5, p. 549, pl. 110Ac, 1916.

-- Holland, Butterfly Book, 2d Ed.,

p. 168, 1931.

- Macy and Shepard, Butterflies,

p. 132, 1941.

Descriptive noteg. The wings are russet brown 
marked with dark brown. The fore wing has two brown spots and a bar in the cell and is crossed by two irregular rows of white splotches. There is also a large black spot ringed by the ground color in cell $\mathrm{Cu}_{1}$ of the fore wing. The hind wing has a submarginal row of six spots simlar to that on the fore wing. The wing expanse varies from one and three quarter inches in the male to two and a quarter in the female.

a. Subspecies A. celtis alicia (Bdwards) firat appeared in Jefferson county, Kentucky on June 18, 1946. It was flying swiftly about a maple (Acer) tree and lighting upon its leaves at intervals. The species became rather common, always being found about trees, and continued so until the end of the study. Food Plants. There is a single food plant which is the Hackberry or celtis occidentalis. Distribution notes. This subspecies normally ranges from Texas through the Gulf states to 
Florida (Fleld, 1938, p. 103). Kentucky is probably at the northern edge of its range although Macy and Shepard (1941, p. 132) mention the occurrence of the species from southern Pennsy lvania and central Minnesota.

\section{Anaea andria Scudder}

Goatweed Butterfly

Anaea andr1a Scudder, Bulletin of the Buffalo Society of Natural Sciences, No. 2, p. 248 , 1875.

-.- Scudder, Butterflies of the Eastern United States and Canada, vol. 3, p. 1794, 1889.

-..- comstock and comstock, How to Know the Butterflies, p. 177, p1. 29, 1904.

--- Rober in Se1tz, Macrolepldoptera

of the World, Vol. 5, p. 581, pl. $117 \mathrm{e}$, 1916.

--- Holland, Butterfly Book, 2d Ed., p. 173, 1931 .

--- Macy and Shepard, Butterflies, p. 135, 1941. 
Pyrrhanaea andria Holland, Butterfly Book, p. 192, pl. 24, 1898.

Descriptive notes. The Goatweed Butterfly is easily recognized by the shape of its wings and by its bright orange color. The fore wings are very pointed and the tip is curved forming an excellent example of a falcate wing. The male is solld orange above with dusky brown borders all around both wings. The only other marking is a short bar of black across the end of the fore wings' cell. The female is the same with the ground color usually somewhat lighter. Across the outer third of the wing there rung a broad band of light brown or $\tan$ which is bounded on each side by a narrow darks brown line. Underneath both sexes are a dead-leaf brown. The wings reach two and a half inches in span. a. While the writer was walking across a recently worked field upon which there was not a sprig of any plant growing, he was startled to have the brilliant red wings of 
A. andria flash before him as it took flight. The butterfly had been resting with closed wings upon a bare clod where its brown under surface blended perfectly with the earth. Th1s was on March 27, 1946 in Jefferson county. The species was not seen again unt1l July 8 , after whlch 1t was occasionally seen throughout the rest of the study. It was often about the decaying fruit in the orchard. Food Plants. croton (croton or Goatweed).18 the food plant of this species. Distribution noteg. The distribution is fairly limited. It occurs in Texas and from there north to Nebraska and east as far as Indlana, Tennessee and Georgia. This occurrence of 1t in Kentucky is therefore on the eastern edge of 1 ts range.

\author{
Family LIBYTHEIDAE \\ The Long-beaks
}

30. Libythea bachmani1 Kirtland 
69.

The Snout Butterfly

Ilbythea bachmani1 Kirtland, American Journal

of Sclence, No. 63, Berles 2, Vol. 13.

pp. 336-37 and $\mathrm{flg}_{\mathrm{g}}, 1852$.

--- Holland, Butterfly Book, p. 227,

pls. 5 and 28, 1898.

-.-- Holland, Butterfly Book, 2d Ed.,

p. 210, 1931.

--- Clark, U.S. Natl. Mus. Bull.,

No. $157, \mathrm{p} .128, \mathrm{p} 1.6,1932$.

--- Macy and Shepard, Butterflies,

p. 137, 1941.

Hypatue bachmanif Scudder, Butterflies of

the Eastern United States and Canada, Vol.

1. p. $760,1889$.

-.-- comstock and comstock, How to

Know the Butterfl1es, p. 210, 1904.

Ibythea carinenta form bachmani seltz,

Macrolepldoptera of the World, Vol. 5 .

p. 623, pl. 120De, 1916. 
Descriptive notes. There is one characteristic possessed by this butterfly which distinguishes 1t at a glance from any other specles found in the Eastern United States. It is the unusual form of the labial palpi which are produced in length to resemble a nout. They actually extend about half the length of the antennae. The upper side of the wings are a dark gray with rather large red areas in the centers and several white spots near the apices of the fore wings. The expance is one and threequarters inches.

a. This specles was caught in Jefferson county on July 30, 1946. Two specimens were found about a tiny pool of water in a hollow in a bluegrass pasture. They were apparently seeking the water. It was the only time that the butterfly was seen during the observations. Food Plants. The only food plant is the hackberry, celtis.

Distribution notes. L. bachmanil occurs 
sparingly in New England and from there south over the rest of Eastern United States.

\section{Family IYCAENIDAE}

The Gossamer-winged Butterflies

Subfami ly THECLINAE

The Hairstreaks

31. Strymon cecrops (Fabricius)

Cecrops Hairstreak

Hesperia cecrops Fabricius, Entomologia

Systemat1ca, Vol. 3, p. 270, 1793.

Calycopis cecrops Scudder, Butterflies of

the Eastern United States and Canada, Vol.

3. p. 1821, 1889.

-..- Comstock and comstock, How to

Know the Butterflies, p. 231, p1. 34, 1904.

Thecla cecrops Holland, Butterfly Book,

p. 246, pls. 29 and $30,1898$.

---- Draudt in Seitz, Macrolepidoptera

of the World, Vol. 5, p. 795, pl. 158b, 1920. 
Strymon cecrops Macy and Shepard, Butterflles, p. $147,1941$.

Descriptive notes. This species is a dark brown with, in some individuals, a declded bluish coloring. The female has several black spots near the margin of the hind wing. Below the wings are crossed by a narrow band of white and just inside it a consplclous band of red. There are two marginal black spots in the hind wing tinged with gray and red. There is an anal spot which is also black and lined with white and red. The only other hairstreak which might be confused with this species is Strymon titus (Fabricius) which also has red coloring underneath. The two are easily distingulshed in fresh specimens, however, by the presence of the two tiny tails characteristic of the hairstreaks in S. cecrops which are not present in S. titus. a. A single specimen of this species was taken in Jefferson county on July 30 , 
1946. The butterfly was not observed here again. It was feeding upon the blooms of 1ronweed, Vernonia noveboracensis. Food Plants. Field (1938, p. 142) says that the food plant of this species is apparently unknown, wh1le Macy and Shepard (1941, p. 147.) refer to scudder as stating that the caterpillar probably feeds on the huckleberry (Vaccinium). Diatribution notes. This is a southern species. It is reported by Macy and Shepard (1941, p. 147) as ranging as far north as Kentucky and West virginia. The finding of it in this county which is at the north edge of Kentucky would probably be an extension of its range.

SUbFanily LYCAENINAE

The Coppers

32. Iy caena hypophleeas (Bo1sduval)

American copper

Polyommatus hypophlaeas Boisduval, Annales de

Ia Soclete Entomologique de France, series

2, Vol. 10, p. 291, 1852 .

Heodes hypoph laeas Scudder, Butterflies of 
the Eastern United States and Canada,

Vol. 2, p. $998,1889$.

--- Comstock and comstock, How to

Know the Butterflies, p. 241, p1. 36, 1904.

Chrysophanus hypophleeas Holland, Butterfly Book, p. 254, pla. 5 and 28, 1898.

---- Draudt in Seltz, Macrolepidoptera

of the World, Vol. 5, p. 813, pl. $145 \mathrm{c}, 1920$.

Chrysophanus phlaeas hypophlaeas Clark, U.S.

Natl. Mus. Bull., No. 157, p. 131, pl. 22 , 1932.

Iy caena hypophlaeas Macy and Shepard, Butterflies, p. 167, p1. 2, 1941.

Descriptive notes. The upper side of the fore wing is brilliant orange. It has a heavy black border on the outer margin. There are several black spots in the orange area. The hind wing is dark brown with a very bright reddish-orange band on the outer margin. The expanse is one inch. There is another copper which is so similar to hypophlaeas that it is almost impossible to write descriptions which 
w1ll distinguish them. The other copper is the female of Ircaena thoe (Gray). The sizes of the two will serve to distinguish them, however. As a contrast to L. hypophlaeas expanse of one inch that of $L$. thoe is always about one and a half inches.

a. Hypophlaeas was captured in Jefferson county on April 30, 1946. The day was very cloudy with intermittent rain showers. This butterfly was frightened into flight from the pasture grasses where it had been resting. It was the only observation of the species that season.

Food Plants. Rumex acetosella Linnaeus which is commonly known as sheep sorrel or dock. Distribution notes. This is one of the northern species. It is found over southern Canada and as far south in the United States as Pennsy lvania, Kansas and in the Appalachian Mountains into Georgla (Field, 1938, p. 158). This occurrence in Kentucky would seem, therefore, to be an extension of 1ts known 
range south and west in this part of the country •

\section{Subfamt ly PLEBEIINAE}

The Blues

33. Everes comyntas (Godart)

The Eastern Tailed Blue

Polyommatus comyntas Godart, Encyclopedie

Method1que, Vol. 9, p. 660, 1924.

Everes comyntas Scudder, Butterfiles of the

Eastern United States and Cenada, Vol. 2,

p. 911, 1889.

-.-- Comstock and comstock, How to

Know the Butterflies, p. 254, pl. 37, 1904.

-..- Draudt in Seitz, Macrolepidoptera

of the Worla, Vol. 5, p. 818, pl. 1441, 1921.

--- Clark, U.S. Natl. Mus. Bull.,

№. 157, p. 133, p.l. $22,1932$.

--- Macy and Shepard, Butterflies,

p. 170, pl. 2, 1941.

Iv caena comyntas Holland, Butterfly Book, 
p. 268, pls. 5, 31, and 32, 1898 .

Descriptive notes. This butterfly is typically a blue in appearance. The female is a dark gray, almost slate gray in color above. There are two marginal black spots capped with orange at the back of the hind wing. The male is the sex presenting the blue ground color and having a broad margin of black around the outer edges. Below both are lighter gray with two rows of dark spots crossing the wings. There are black points at the back of the hind wings tipped with metallic green and with orange. E. comyntas may most easily be recognized by its tails which occur one on each hind wing and which no other blue has.

a. It was first taken in Jefferson county on May 28, 1946. From that time it was perhaps the most common of all butterflies. Dozens Ined the moist edges of the creeks and other dozens could be found on the clover and blackberry blossoms. It was almost as common at 
the end of the study on August 21.

Food Plants. Trifolium or clover, Lespedeza,

Phaseolus or bean, and other legumes.

Distribution notes. Everywhere east of the Rocky Mountains in the United States and routh to costa Rica.

34. Ivcaenopsis argiolus peeudargiolus (Boisduval and Leconte) Spring Azure

Argus pseudarg10lus Boisduval and Leconte,

Lepldopteres de I'Amerique septentrionale, p. 118, pl. $36,1833$.

cyaniris pseudarg10 lus Scudder, Butterflies of the Eastern United Stater and Canada, Vol. 2, p. 927, 1889.

Ivcaena pseudarg10lus Holland, Butterfly Book, p. 267, pls. 5, 30 and 31, 1898 . cyaniris ladon comstock and comstock, How to Know the Butterflies, p. 249, p1. 38, 1904. -.- Draudt in Seitz, Macrolepidoptera of the Forld, Vol. 5, p. 818, pl. 144b, 1921. 
Iycaenopsis arg10lus pseudargiolus Clark, U.S. Nat1. Mus. Bull., No. 157, p. 136, p1. 22, 1932 .

-.-- Macy and Shepard, Butterflies,

p. 176, 1941.

Descriptive notes. It is very difficult to give a description of this species. It is found throughout the whole Northern Hemisphere and in the United States alone there are seven subspecies and many forms. Pseudargiolus is the subspecies found throughout the entire United States, east of the Rocky Mountains. Typically it is entirely violet-blue above. There are no dark markings on this side. The underside is whitish with numerous elongate or square black spots. The row of black points along the outer margin is set off from the rest of the wings by a row of gray crescents. The expanse is one and a quarter inches. a. Typical L. a. pseudarsiolus was taken in Jefferson county on April 26, 1946. It was not seen again. 
b. L. argiolus pseudargiolus form neglecta Edwards was netted in this county on May 23. The specimen was identified by Mr. Don B. stallings of Caldwell, Kansas.

c. L. argiolus pseudarg10lus form neglectamajor Tutt, was caught in this county on July 27, 1946. It also was identifled by Mr. Stallings.

The butterfly was not common, the three described above being the only ones seen during the study.

Food Plants. Typical pseudargiolus, the spring brood, lays its eggs upon Svida (dogwood). Form neglecta, the second brood deposits its eggs on Tium racemosum Pursh (rattleweed). The third brood, form neglecta-major, lays Its egg on Verbesina hellanthoides Michx (crown beard) (Field, 1938, p. 173). Distribution notes. The species L. argiolus, as stated above, ranges over all of the Northern Hemlsphere. Subspecies pseudargiolus ranges throughout Eastern United States. 


\author{
Fam1ly HESPERIIDAE \\ The Skippers \\ Subfamily PYRGINAE \\ 35. Proteldes clarus (cramer) \\ S1Iver Spotted Skipper
}

Papilio tityrug Fabricius, Entomologia

Systematica, p. 532, 1775.

Pap1110 clarue Cramer, Papilions Bxotiques,

Vol. 1, p. 66, pl. 41, 1779.

Epargyreus tityrus Scudder, Butterflies of the

Eastern United States and Canada, Vol. 2,

p. 1399, 1889.

--- Holland, Butterfly Book, p. 323.

pls. 2, 6, and 48, 1898.

-.-- comstock and Comstock, How to

Know the Butterflies, p. 293, pls. 14 and 43 , 1904.

---- Lindsey, Bell, and Williams,

Denison University Bulletin, Vol. 3l, p. 20, 1931.

--- Clark, U.S. Natl. Mus. Bull.,

No. $157, p .202, p 1.50,1932$. 
Proteides tityrus Williams and Bell, Transactions of the American Entomological Society, Vol. 59, p. 69, 1933.

Epargyreus clarus Hemming, The Generic Names of the Holarctic Butterflies, Vol. 3, p. 199, 1934.

Proteldes clarus Macy and Shepard, Butterflies, p. 181, 1941.

Descriptive noteg. This is the largest skipper common in this area. Its wings may measure one and three quarters inches or even sometimes two inches. It is easily recognized by the large silver spot on the underside of the hind wing and by the gold colored band across both the upper and underside of the fore wing.

a. This conspicious butterfly was first found in Jefferson county on May 3, 1946. It was feeding upon the blooms of blackberry. It was very common throughout the study. Food elants. The larva feed upon Robina pseudacacla L. (locust) and Fistaria (wistaria). 
Distribution notes. It ranges throughout the United States into South America.

\section{Pholisora catulius (Fabricius)}

The common Sootywing

Hesperia catullus Fabricius, Entomologia

Sy stematica, Vol. 3, p. 348, 1793.

Pholisora catullus Scudder, Butterflies of

the Eastern United States and Canada, Vol.

2, p. 1519, 1889.

-.- Holland, Butterfly Book, p. 330 ,

pls. 6 and $45,1898$.

---- Comstock and comstock, How to

Know the Butterflies, p. 297, p1. 44, 1904.

-.- Iindsey, Bell, and W1Lliams,

Denison University Bulletin, Vol. 31, p. 52, 1931.

--- clark, U.S. Natl. Mus. Bull.,

No. 157, p. 208, 1932.

-.- Macy and Shepard, Butterflies,

p. 189, 1941. 
Descriptive notes. Black ground color with a submarginal row of small white spots on the forewings. The outer margins of the wings are rounded.

a. This skipper was caught in Jefferson county on April 22, 1946. It was feeding on the blooms of dandelion (Taraxacum). The specimen was identified by $\mathrm{Mr}$. Stalings. The butterfly was seen occasionally until the end of the study.

Food Plants. Ambrosia (ragweed), Chenopodium album Linnaeus (lamb's quarter), and Amaranthus (pigweed).

Distribution notes. It is found throughout the entire United States.

37. Pholigora hayhurgtil (Edwards) Hayhurst's Sooty wing

Hesperia hayhurstil Edwards, Transaction of the American Entomological Society, Vol. 3. p. 22,1870 . Pholisora hayhurstif Scudder, Butterflies of the Eastern United States and Canada, Vol. 3, 
p. 1857, 1889.

--- Holland, Butterfly Book, p. $331, p 1.48,1898$.

-..- Iindsey, Bell, and Williams,

Denison University Bulletin, Vol. 31,

p. 54, 1931.

--- Macy and Shepard, Butterflies,

p. $190,1941$.

Descriptive notes. This is another dark

colored skipper but it is easily recognized

by the shape of its hind wing which has a

wavy margin and a slight anal lobe. The

upper surface of the wings are crossed by

two dark bands.

a. This skipper was taken in Jefferson

county on May 15, 1946. It was not seen again.

Food Plants. The food plants are unknown.

Distribution notes. From Southern Pennsy-

Ivania south to Florida and west to Kansas

and Texas. Kentucky would thus appear to

be near its northern limit. 
Subfamily HESPERIINAE

38. Ancy loxypha numitor (Fabricius)

Least Skipper

Hesperia numitor Fabricius, Entomological

Systematica, Vol. 3, p. 324, 1793.

Ancyloxipha numitor Scudder, Butterflies of

the Eastern United States and Canada, Vol. 2, p. 1558, 1889.

-m comstock and comstock, How to know

the Butterflies, p. 272, pl. 39, 1904.

Ancy loxypha numitor Holland, Butterfly Book, p. 345, pl. 47, 1898.

--- Lindsey, Bell, and W1lliams,

Denison University Bulletin, Vol, 3l,

p. $71,1931$.

-..- Macy and Shepard, Butterflies, p. 201,

1941.

Descriptive notes. This is the smallest of this subfamily. It is golden above with brown borders about the wings and with an orange ray along the costal margins of the fore wings. Underneath the forewings are brown with orange borders and the hind wings are entirely 
orange.

a. This species was observed as a slowly flying inhabitor of the dense marsh grasses along a small creek in Jefferson county on June 20, 1946. It was last seen there on July 16. The 1dentification was by Mr. Stalings. Food Plants. Spartina (marsh grass) is the food plant.

Distribution notes. Although seldom noticed it occurs throughout Eastern United States west to the Rocky Mountains.

39. Polites themistocles (Latreille) The Tawny-Edged Skipper

Pap1110 taumas Fabricius, Mantissa Insectorum, Vol. $2, p .84,1787$.

Hesperia themistocles Latreille, Encyclopedie Methodique, Vol. 9, p. 723, 1824. Hesperia cernes Bolsduval and Leconte, Lepidopteres de I'Amerique septentrionale, pl. 76, 1833. Iimochores taumas scudder, Butterflies of the Eastern U.S. and Canada, Vol. 2, p. 1725, 1889. 
-..- Holland, Butterfly Book, p. 357,

pls. 6 and $47,1898$.

Thymelicus cernes comstock and comstock, How to Know the Butterflies, p. 281, p1. 41, 1904.

Polites taumas Holland, Butterfly Book, 2d Ed., p. 381, pls. 6, 47 and 53, 1931.

Talides themistocles Lindsey, Bell and Williams, Denison University Bulletin, Vol. 31, p. 100, 1931.

Polltes cernes Clark, Bulletin of the U.S. NatI. Museum, No. 157, p. 222, pl. 49, 1932.

Polites themistocles Macy and Shepard, Butterflies, p. $216,1941$.

Descriptive notes. In the male the hind wing is plain olive brown both above and below. The fore wing is the same color above, but with a large black stigma in the center of the wing. Above the stigma is a large triangle of lighter brown. The female is darker in color without the stigma, of course, and with a group of yellowish hyaline spots on the outer third of the fore wing. 
a. This species was taken in Jefferson county on July 27, 1946. It was feeding upon the blooms of ironweed (Vernonia). It was identified by $\mathrm{Mr}$. Stallings. It was not observed again in this study. Food Plants. Poaceae (grasses) is the food plant. Distribution notes. The entire eastern United States and Canada west to Manitoba, Utah, and New Mexico.

\section{Polites Verna (Bdwards) The Iittle Glassy Wing}

Pamphila verna Edwards, Proceedings of the Academy of Natural Sclence of Philadelphia, p. 57,1862 .

Euphyes verna Scudder, Butterflies of the Eastern United States and Canada, Vol. 2, p. $1742,1889$. --. Holland, Butterfly Book, p. 360 , p1. $46,1898$. -..-' Comstock and Comstock, How to 
Know the Butterflies, p. 283, p1. 41, 1904.

Talides verna Lindsey, Bell, and Williams, Denison University Bulletin, Vol. 31, p. 99, 1931.

Polites Verna Holland, Butterfly Book, $2 d$ Ed., p. $380,1931$.

--- Clark, U.S. NatI. Mus. Bull.,

No. 157, p. 221, pl. 49, 1932.

-.-- Macy and Shepard, Butterflies,

p. 217, 1941.

Descriptive notes. The ground color is dark brown with a group of subapical hyaline spots and several larger ones below those. On the under side there is a row of small light spots.

a. This butterfly was caught in Jefferson county on May 25, 1946. It was seen seldom, but continued as late as August 1. Mr. Stallings checked the identification. Food Plants. The food plant of this species Is Poaceae (grass).

Distribution notes. It is found throughout the eastern United States. 


\section{Polites peckius (Kirby) Peck's Skipper}

Hesperia peckius Kirby, Fauna Boreali American1, part 4, p. 300, pl. 4, 1837.

Polites pecklus Scudder, Butterfiles of the Eastern United States and Canada, Vol. 2, p. $1683,1889$. ---- Holland, Butterfly Book, p. 353, pl. $47,1898$. --- Comstock and comstock, How to Know the Butterflies, p. 282, p1. 41, 1904. -.-- Macy and Shepard, Butterflies, p. 218, 1941.

Talides peckius Iindsey, Bell and Williams, Denison University Bulletin, Vol. 3l, p. 102, 1931.

Polites coras Clark, U.S. Natl. Mus. Bull., No. 157, p. 220, pl. 49, 1932. Descriptive notes. This is a small skipper. It is dark brown with several yellow lshorange spots and a patch of yellowish orange on the fore wing. Underneath the wing are 
dark brown with a number of large yellow, square spots on the hind wings and smaller spots on the fore wings.

a. This skipper was taken on July 27, 1946 in Jefferson county. It was found on blooming wild carrot (Daucus carota). The identification was by Mr. Stallings.

Food Plants. This species feeds on Poaceae (grasses).

Distribution notes. This species is found in the Eastern United States.

42. Poanes zabulon (Bolsduval and Leconte)

The Zabulon Skipper

Hesperia zabulon Bolsduval and Leconte,

Lepidopteres de l'Amerique Septentrionale, pl. $76,1833$.

Atrytone zabulon comstock and comstock, How to know the Butterflies, p. 274, pl. 39, 1904.

Poanes zabulon Lindsey, Bell, and williams, Denison University Bulletin, vol. 3l, p. 110, 1931. 
-.-- Holland, Butterfly Book, 2d Ed.,

p. 390, p1. 53, 1931.

-m Clark, U.s. Natl. Mus. Bull.,

No. 157, p. 230, pl. 54, 1932.

--- Macy and Shepard, Butterflies, p.

223, 1941.

Descriptive notes. This species and another

P. hobomok are so similar that they are

almost ldentical on the upper side and on

the under side of the fore wing. On the

underside of the hind wing zabulon is mostly

yellow with two large brown spots at the base

of the wing, several brown spots in the center

and a broken brown border around the margin.

There is a lso a brown streak slightly in from

the inner margin. The female is distinguished

by the reddish-brown ground color of 1 ts

underside.

a. This species was captured in Jefferson county on May 6, 1946, feeding upon clover blooms. It was seen occasionally during all the rest of the study. The identification 
was by Mr. Stallings.

Food Plants. The food plant of this species

1a Poaceae (Erass).

Distribution notes. This species is found throughout most of the eastern United States. 
IIFE 2ONES; LOCAL REGIONS OF THE COUNTY, AND COMPARATIVE LISTS

Kentucky lies within the carolinian Iffe zone. Jefferson county is not divided by these large zones. The only division of the county which could, therefore, hold any significance as far as the fauna is concerned are those arising from the geological formations of the county. An effort was made to secure lista of the butterflies occuring in these different areas for comparative study to ascertain whether or not certain species are limited to certain of these areas. The result was as a whole disappointing for there were few instances of such restrictions in the range of any species. Two factors probably are responsible for this result. One is the extreme motility of butterflies which can fly quickly and easily across the whole county at will. The other 1s the rarity of many of the species concerned which were seen only once during the whole 
study. Because of their rarity the chances against finding them on a few hours collecting trip into an area was so great that it must be conceded that they could have been as numerous there as anywhere else and still not have been observed at all. The importance of this latter fact is only felt when it is realized that of the forty-two species found, fifteen or over a third were only seen once in any area.

The regions of the county are the follow1ng: (1) Outer Bluegrass (featured by Ordoviclan limestone), (2) Muscatatuck Regional Stope (Devonian Limestone), (3) Scottsburg Low land (New Albany Shale), (4) Oh10 River Valley proper, (5) The knobs. These regions are indicated on the accompanying map of the county .

A list of the species follows with indications of regions in which they were observed. 


\begin{tabular}{|c|c|c|c|c|c|}
\hline & $\left\{\begin{array}{l}\text { River } \\
\text { Valley }\end{array}\right.$ & $\begin{array}{l}\text { Scotss } \\
\text { burr } \\
\text { Lowland }\end{array}$ & 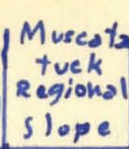 & $\mid \begin{array}{l}\text { outer } \\
\text { olter } \\
\text { gross }\end{array}$ & $\begin{array}{l}\text { The } \\
k_{n} \circ b\end{array}$ \\
\hline Pap1110 ph1lenor & $x$ & $x$ & $x$ & $x$ & $x$ \\
\hline Pap1110 a jax & $x$ & $x$ & $x$ & $x$ & $x$ \\
\hline Pap1l10 g laucus & $x$ & $x$ & $x$ & $x$ & $x$ \\
\hline Papilio troilus & $x$ & & $x$ & $x$ & \\
\hline Pap1l10 marcellus & & $x$ & & $x$ & \\
\hline Anthocharis midea & & & & $x$ & \\
\hline collas philodice & $x$ & $x$ & $x$ & $x$ & $x$ \\
\hline Phoebis sennae eubule & & $x$ & & & \\
\hline Eurema 1isa & & & & & $x$ \\
\hline Eurema nicippe & & & & $x$ & \\
\hline Pleris protodice & $x$ & $x$ & $x$ & $x$ & $x$ \\
\hline Pieris rapae & $x$ & $x$ & $x$ & $x$ & $x$ \\
\hline Danaus plexippus & $x$ & $x$ & $x$ & $x$ & $x$ \\
\hline Megisto eurytus & $x$ & $x$ & $x$ & $x$ & $x$ \\
\hline Dione vanillae & & & $x$ & & \\
\hline Argynnis aphrodite & $x$ & $x$ & $x$ & $x$ & $x$ \\
\hline Phyclodes gorgone & & & & $x$ & \\
\hline Phyclodes nycteis & $x$ & $x$ & $x$ & $x$ & $x$ \\
\hline Phyciodes tharos & $x$ & $x$ & $x$ & $x$ & $x$ \\
\hline Polygonia interrogationis & $x$ & $x$ & $x$ & $x$ & $x$ \\
\hline Nymphalis antiopa & & & & $x$ & \\
\hline Vanessa atalanta & $x$ & $x$ & $x$ & $x$ & $x$ \\
\hline Vanessa virginiensis & & & $x$ & $x$ & $x$ \\
\hline Vanessa cardu1 & $x$ & $x$ & $x$ & $x$ & $x$ \\
\hline
\end{tabular}




\begin{tabular}{|c|c|c|c|c|c|}
\hline & $\begin{array}{l}\text { River } \\
\text { rolley }\end{array}$ & $\left|\begin{array}{l}\text { Scoths- } \\
\text { burs } \\
\text { Lowland }\end{array}\right|$ & 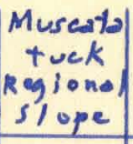 & 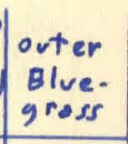 & \begin{tabular}{|l|} 
The \\
Knobs
\end{tabular} \\
\hline Junonia coenia & & & & $x$ & \\
\hline Basilarch1a astyanax & $x$ & $x$ & & $x$ & $x$ \\
\hline Bas1larchla archiopus & $x$ & & $x$ & & \\
\hline Asterocampa celtis & $x$ & $x$ & $x$ & $x$ & $x$ \\
\hline Anaea andria & & & $x$ & $x$ & $x$ \\
\hline Libythea bachmani1 & & & & $x$ & \\
\hline Strymon cecropgs & & & & $x$ & \\
\hline Iycaena hypophlaeas & & & $x$ & & \\
\hline Everes comyntas & $x$ & $x$ & $x$ & $x$ & $x$ \\
\hline$\frac{\text { IV caenopsis argiolus }}{\frac{\text { pseudargiolus }}{10}}$ & & & & $x$ & \\
\hline Proteides clarus & $x$ & $x$ & $x$ & $x$ & $x$ \\
\hline Pholisora catullus & & $x$ & $x$ & $x$ & $x$ \\
\hline Pholisora hayhurstil & & & & $x$ & \\
\hline Ancy loxypha numitor & & & $x$ & & \\
\hline Polites themistocles & & & $x$ & & \\
\hline Polites verna & & & $x$ & & \\
\hline Polites peckius & & & & $x$ & \\
\hline Poanes zabulon & & & $x$ & $x$ & $x$ \\
\hline
\end{tabular}




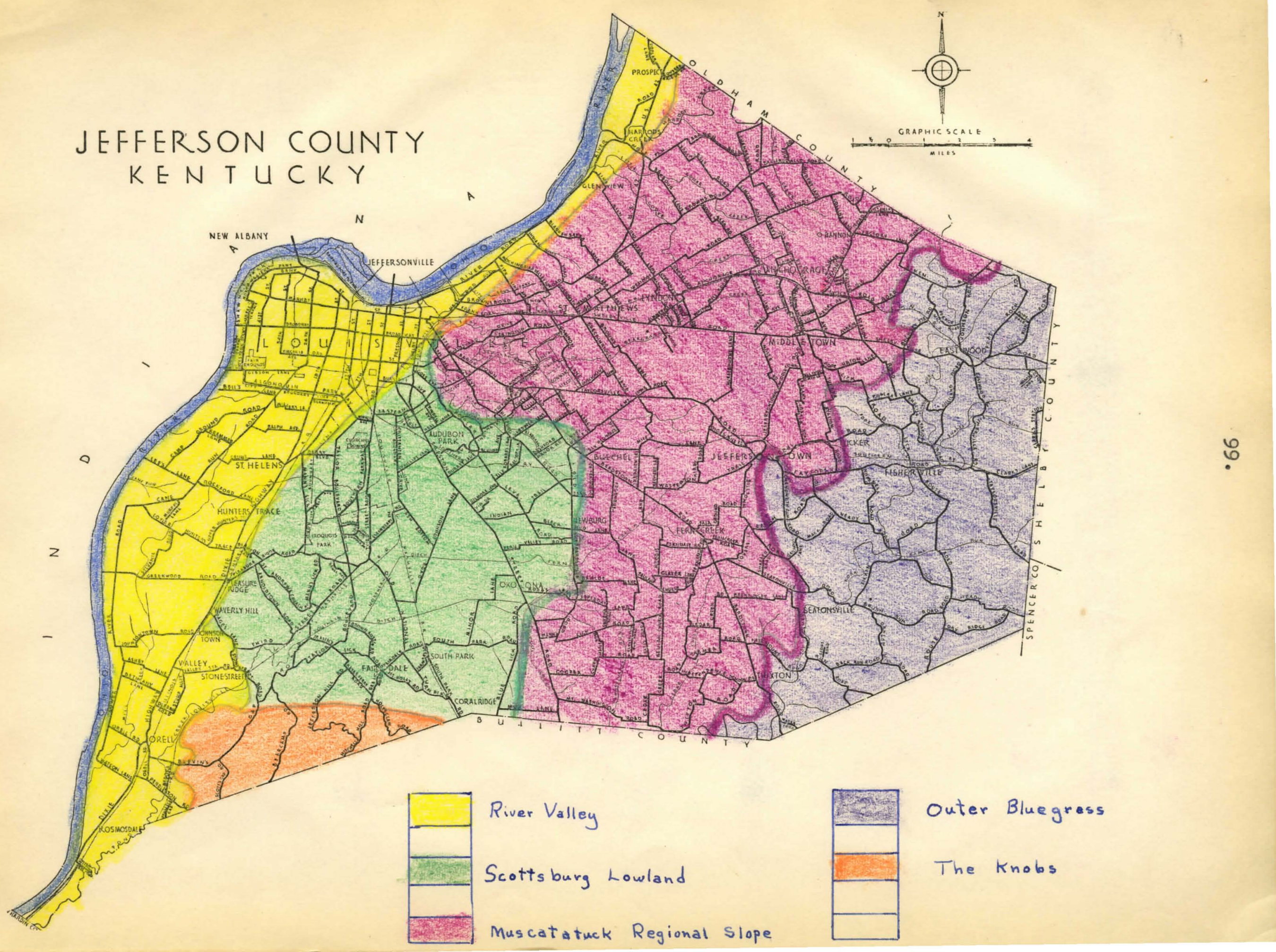




\section{BIBLIOGRAPHY}

\section{Bo1 sduval, J.A.}

1852. Annales de la societe Entomologique de France, sertea 2, Vol. 10.

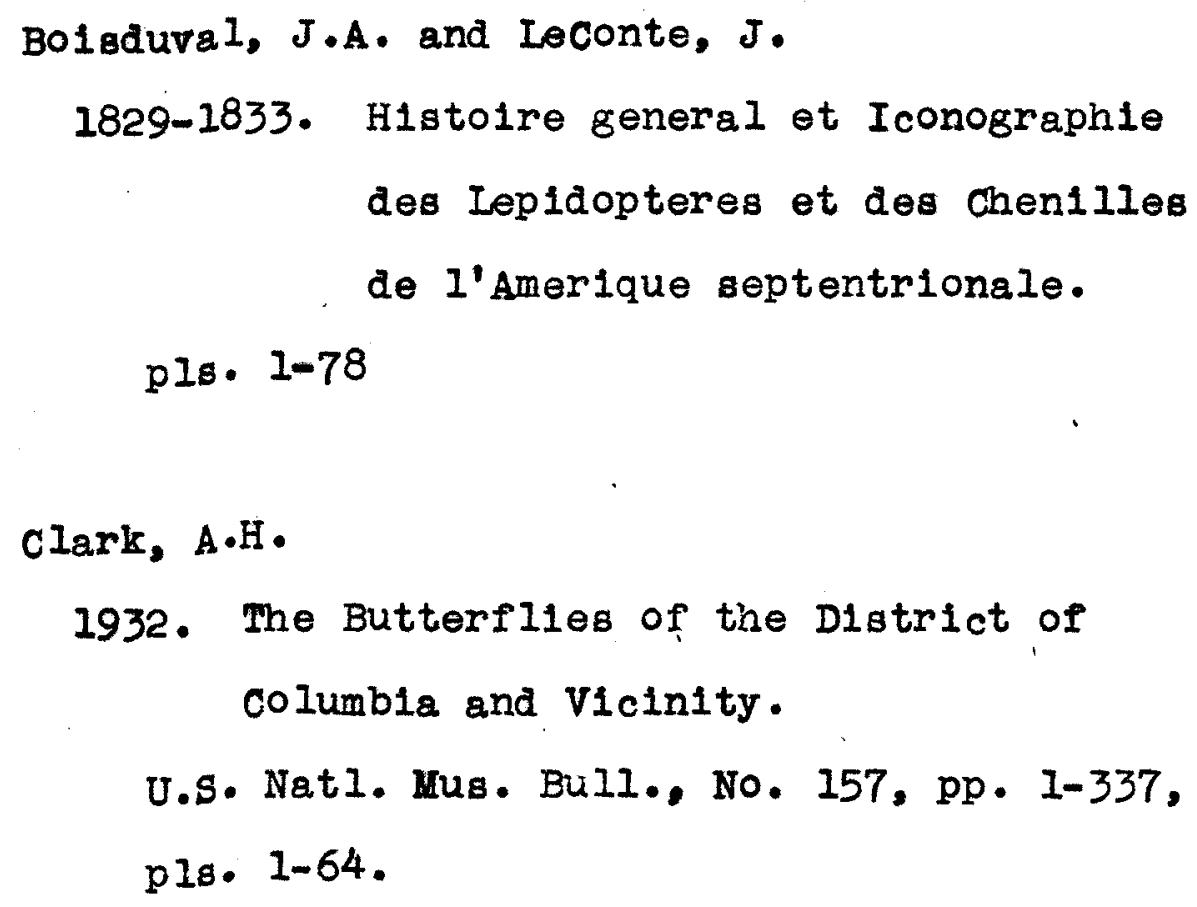


Comstock Publiohing Co., Ithica, N.Y. pp. 1-311, pls. 1-45.

cramer.

1779-1782. Papillons Bxotiques.

d'Almeida.

1936. Revisao das Terias americanus.

Memorias do Instituto Oswaldo cruz. No. 31.

Doubleday, E., Westwood, J.0., c and Hewitson, W.C.

1846-1852. Genera of Duirnal Lepidoptera.

vol. 1-2, pp. 1-534, pls. 1-86.

Drury, Drv.

1770. Illustrations of Natural History.

Edwards, $\mathbb{T}$.

1862.

Academy of Natural Science of Philadelphia

Proceedings.

1870 . 
Transactions of the American Entomological Soclety, Vol. 3 .

Fabricius, J.C.

1787. Mant1ssa. Insectorum.

Vol. 2 .

1793-1794. Entomolog1a systematica.

Vo1. 3, pp. 1-349.

1798. Supplementum Entomologlae Systemat1cae. pp. 1-572.

Field, W.D.

1938. A Manual of the Butterflies and Skippers of Kansas.

University of Kansas Bulletin. Vol. 39, No. 10, pp. 1-328.

Godart

1819. Encyclopedie Methodique.

Hemming F.

1934. The Generic Names of the Holarctic Butterflies.

Vol. 3. 
Holland, W.J.

1898. The Butterfly Book.

Doubleday \& McClure Co., New York.

Hubner, $J$.

1806-1841. Sammlung Exotischer Schmetterlinge. pls. $1-491$.

1819. Verzeichniss Bekannte Schmetterlinge.

Kirby, $\pi$.

1837. Fauna Boreal1 Americana.

Part 4. pp. 1-325, pls. 1-8.

Kirtland.

1852.

American Journal of Science No. 63.

Series 2, Vol. 13.

Latre1lle.

1824. Encyclopedie Methodique.

Vol. 9.

Iindsey, A.W., Bell, E.I., and Williams, R.C. Jr. 
1931. The Hesperioldea of North America. Denison University Bulletin, Vol. 31, Journal of the Scientific Laboratories, Vol. $26, \mathrm{pp} .1-142, \mathrm{pls} \cdot 1-33$.

Linnaeus (Carl von Iinne).

1758. Syвtema Naturae. 10th Ed.

1768. Systema Naturae. 12th $\boxplus d$.

1771 Mantissa Plantarum.

Macy, R.W. and Shepard, H.H.

1941. Butterflies.

The University of Minnesota Press, Minneapo 1is, Minnesota. pp. 1-247, ple. 1-4, Photos 1-38.

MeDunnough, $J$.

1938. Check Ifst of the Lepidoptera of Canada and the United States of Amer1ca. Part 1, Macrolepidoptera. Memolra s. Cal. Acad. Scl., Vol. I, pp. $1-275$. 
scudder, S.H. 1875.

Bulletin of the Buffalo soclety of Natural Sclences, No. 2.

1889. The Butterflies of the Eastern United Stater and Canada, with Speclal Reference to New England. Cambridge, Mass., Vols. 1-3, pp. 1-1958, pls. 1-89, maps 1-4.

Seitz, A. (editor). 1907-1924. The Macrolepidoptera of the World, Vol. 5, The American Rhopolocera. stuttgart. pp. 1-1139, pls. $1-203$.

W11liams and BeIl. 1933. American Entomological soclety Transactions. vol. 59. 